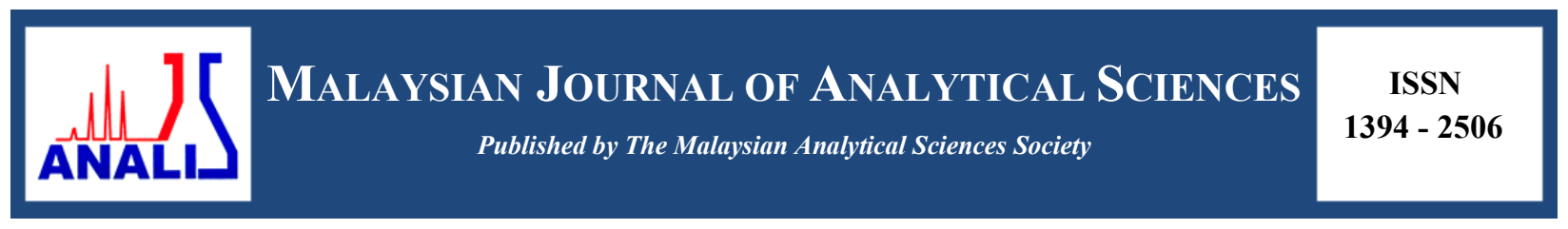

\title{
OPTIMIZATION PARAMETER FOR THERMOELECTRIC PROPERTIES OF ZnO USING RESPONSE SURFACE METHODOLOGY
}

\author{
(Pengoptimuman Parameter Untuk Sifat Termoelektrik ZnO Menggunakan \\ Kaedah Gerak Balas Permukaan) \\ Lim Joon Hoong*, Yeoh Cheow Keat, Abdullah Chik, Teh Pei Leng \\ School of Materials Engineering, \\ Universiti Malaysia Perlis, 02600 Jejawi, Perlis, Malaysia \\ *Corresponding author: jhlim07@gmail.com
}

Received: 5 January 2016; Accepted: 23 May 2016

\begin{abstract}
The effect of $\mathrm{Al}$ dopants and sintering temperature on thermoelectric properties of $\mathrm{ZnO}$ was studied using the response surface method. The design of experimental work was performed with the response surface method used to determine the significant level of factors which are sintering temperature in the range of $800-1000{ }^{\circ} \mathrm{C}$ and $\mathrm{Al}$ dopants in the range of $0-4$ wt.\%. The thermoelectric properties of $\mathrm{Al}$-doped $\mathrm{ZnO}$ were enhanced with increasing $\mathrm{Al}$ dopants and slightly decreased when increasing sintering temperature. Additional phase $\mathrm{ZnAl}_{2} \mathrm{O}_{4}$ was detected for 3 wt.\% and 4 wt.\% Al-doped $\mathrm{ZnO}$ pellets as the sintering temperature increased to $1000{ }^{\circ} \mathrm{C}$. The presence of $\mathrm{ZnAl}_{2} \mathrm{O}_{4}$ phase slightly decreased the electrical conductivity compared to single $\mathrm{ZnO}$ phase samples. The optimum parameter values for this study was $\mathrm{Al}$ dopant (4 wt.\%) and sintering temperature (800 ${ }^{\circ} \mathrm{C}$ ). The effect of $\mathrm{Al}$ doping to the band structure of $\mathrm{ZnO}$ was studied using first-principles based on density functional theory (DFT). The calculated band structure of $\mathrm{ZnO}$ and $\mathrm{Al}$ doped $\mathrm{ZnO}$ shows that $\mathrm{ZnO}$ is a direct band gap semiconductor. The calculated band gap of $\mathrm{ZnO}(0.749 \mathrm{eV})$ become smaller with the concentration of Al doping increased to $4 \mathrm{wt} . \%(0.551 \mathrm{eV})$. The trend of the calculated band gap of Al-doped $\mathrm{ZnO}$ was in agreement with the electrical conductivity test results which increased with increasing $\mathrm{Al}$ content. However, it must be noted that the software predictions do not take into account the presence of additional $\mathrm{ZnAl}_{2} \mathrm{O}_{4}$ phases. The presence of these extra phases may lead to even lower electrical conductivity.
\end{abstract}

Keywords: Al-doped $\mathrm{ZnO}$, response surface method, sintering temperature, thermoelectric, electronic band structure

\begin{abstract}
Abstrak
Kesan Al dop dan suhu pembakaran ke atas termoelektrik ZnO dikaji dengan menggunakan kaedah gerak balas permukaan. Reka bentuk kerja eksperimen telah dilakukan dengan kaedah gerak balas permukaan untuk menentukan aras signifikan suhu pembakaran pada julat $800-1000{ }^{\circ} \mathrm{C}$ dan $\mathrm{Al}$ dop dalam lingkungan $0-4 \%$ berat. Sifat - sifat termoelektrik $\mathrm{Al}$-dop $\mathrm{ZnO}$ telah dipertingkatkan dengan peningkatan $\mathrm{Al}$ dop dan pensinteran suhu. Fasa tambahan $\mathrm{ZnAl}_{2} \mathrm{O}_{4}$ dikesan bagi $3 \%$ berat dan $4 \%$ berat Al-dop $\mathrm{ZnO}$ bila suhu pembakaran meningkat daripada $800{ }^{\circ} \mathrm{C}$ hingga $1000{ }^{\circ} \mathrm{C}$. Kekonduksian elektrik menurun dengan kehadiran fasa $\mathrm{ZnAl}_{2} \mathrm{O}_{4}$ berbanding sampel fasa $\mathrm{ZnO}$ tunggal. Nilai - nilai parameter optimum untuk kajian ini adalah $\mathrm{Al}$ pendopan $\left(4 \%\right.$ berat) dan suhu pensinteran $\left(800^{\circ} \mathrm{C}\right)$. Kesan $\mathrm{Al}$ doping kepada struktur jalur $\mathrm{ZnO}$ dikaji menggunakan prinsip pertama berdasarkan teori fungsi ketumpatan. Struktur jalur yang dikira pada $\mathrm{ZnO}$ dan Al dop $\mathrm{ZnO}$ menunjukkan bahawa $\mathrm{ZnO}$ adalah semikonduktor jurang jalur terus. Dengan Al dop, jurang jalur ZnO (0.749 eV) menjadi lebih kecil dengan peningkatan kepekatan Al dop pada 4 wt.\% $(0.551 \mathrm{eV})$. Trend jurang jalur yang dikira pada ZnO Al-didopkan adalah selari dengan keputusan ujian kekonduksian elektrik yang meningkat dengan peningkatan kandungan Al. Walau bagaimanapun, ia perlu diambil perhatian bahawa ramalan perisian tidak mengambil kira kehadiran fasa $\mathrm{ZnAl}_{2} \mathrm{O}_{4}$ tambahan. Kehadiran kedua - fasa tambahan boleh membawa kepada kekonduksian elektrik yang lebih rendah.
\end{abstract}




\section{Lim et al: OPTIMIZATION PARAMETER FOR THERMOELECTRIC PROPERTIES OF ZnO USING RESPONSE SURFACE METHODOLOGY}

Kata kunci: Al dop $\mathrm{ZnO}$, kaedah gerak balas permukaan, suhu pembakaran, termoelektrik, struktur jalur elektronik

\section{Introduction}

Thermoelectric materials could potentially convert heat into electricity through thermoelectric power [1]. The efficiency of energy conversion depends on the thermoelectric figure of merit of the material. Based on the figure of merit, these materials must have the unique combination of high electrical conductivity, high Seebeck coefficient and low thermal conductivity [2]. Seebeck coefficient (S) of a material is the voltage generated between two points in the material per unit temperature difference between these points [3].

Zinc oxide $(\mathrm{ZnO})$ is an II-VI compound semiconductor with a wide direct band gap at room temperature [4]. It is a widely used material in various application such as gas sensors, varistors, UV resistive coatings, piezoelectric devices, surface acoustic wave devices and transparent conductive oxide electrodes [5,6]. The main drawback of $\mathrm{ZnO}$ as thermoelectric materials is due to the low electrical conductivity at room temperature. The electrical conductivity can be increased by special heat treatment and doping of specific impurities into the crystal lattice. In the hexagonal close packed lattice of the $\mathrm{ZnO}$ wurtzite structure, half of the tetrahedral holes and all of the octahedral holes are empty, providing further possible dopant sites [7]. A dopant ion introduced to modify the electronic properties of a material needs to be incorporated into the crystal structure of the host material (either in lattice sites or interstitially). $\mathrm{ZnO}$ can even be made to exhibit metallic conductivity as for transparent electrode similar to Indium tin oxide glass. In general, $0.5-1 \%$ addition of trivalent cations such as aluminium (Al) and chromium $(\mathrm{Cr})$ decrease the resistivity of $\mathrm{ZnO}$ approximately 10 orders of magnitude [8]. Jimenez-Gonzalez et al. [9] explains the increase in the conductivity of $\mathrm{ZnO}$ when $\mathrm{Al}$ is introduced as a dopant, in terms of donor behaviour from $\mathrm{Al}$. Al has one valence electron more than $\mathrm{Zn}$, substitution of $\mathrm{Al}$ for the $\mathrm{Zn}$ atom or $\mathrm{Al}$ occupation of the interstitial sites increases the concentration of charge carriers present in the material.

The properties of $\mathrm{ZnO}$ are related to the composition and phase formation. The conductivity properties of $\mathrm{ZnO}$ can be tailored by controlling the deviation from stoichiometry and doping [10]. Therefore, it is necessarily to understand the effect of the individual dopant element to the electrical properties and phase formation of $\mathrm{ZnO}$. In this work, the effect of $\mathrm{Al}$ dopant $(0-4 \mathrm{wt} . \%)$ and sintering temperature $\left(800-1000{ }^{\circ} \mathrm{C}\right)$ on the thermoelectric properties were studied using the response surface methodology. The band structure of $\mathrm{ZnO}$ with different $\mathrm{Al}$ contents are calculated by first principles method based on Density Functional Theory (DFT) as a comparison for the electrical conductivity.

\section{Chemical and reagent}

\section{Materials and Methods}

Analytical grade $\mathrm{ZnO}$ powder and $\mathrm{Al}_{2} \mathrm{O}_{3}$ powder were used as the starting materials for the preparation of pellet samples. The properties of $\mathrm{ZnO}$ and $\mathrm{Al}_{2} \mathrm{O}_{3}$ were shown in Table 1 .

Table 1. Properties of $\mathrm{ZnO}, \mathrm{Al}_{2} \mathrm{O}_{3}, \mathrm{Fe}_{2} \mathrm{O}_{3}$ and $\mathrm{CuO}$ (HmbG Chemicals)

\begin{tabular}{lll}
\hline Properties & Zinc oxide & Alumina \\
\hline Molecular formula & $\mathrm{ZnO}$ & $\mathrm{Al}_{2} \mathrm{O}_{3}$ \\
Molar mass, $\mathrm{g} / \mathrm{mol}$ & 81.408 & 375.134 \\
Appearance & white solid & white solid \\
Density, $\mathrm{g} / \mathrm{cm}^{3}$ & 5.606 & $3.95-4.1$ \\
\hline
\end{tabular}

\section{Experimental procedure}

Appropriate amounts of $\mathrm{ZnO}$ and $\mathrm{Al}_{2} \mathrm{O}_{3}$ powder were mixed using the solid state method to prepare $0,1,2,3$ and 4 wt.\% Al-doped $\mathrm{ZnO}$. The samples were shaped into pellets of $5 \mathrm{~mm}$ of thickness and $15 \mathrm{~mm}$ in diameter. All 
samples were compacted using a cold hydraulic press machine at $75 \mathrm{MPa}$ for $10 \mathrm{~min}$. The green compact was sintered in furnace (Model HT4-1600-SIC) at different sintering temperature $800{ }^{\circ} \mathrm{C}, 900{ }^{\circ} \mathrm{C}$ and $1000{ }^{\circ} \mathrm{C}$ for 4 hours with heating rate of $10{ }^{\circ} \mathrm{C} / \mathrm{min}$. The synthesized samples were characterized by X-ray diffraction analysis (Shimadzu XRD 2000). The electrical conductivity of the samples was determined by the two-probe method. The current voltage measurements were carried out using a Keithley's source measure unit (Model SMU 236). The thermal conductivity of the samples was determined based on Fourier's law. The Seebeck coefficient was measured by using differential method [11] at room temperature.

\section{Response surface methodology}

Response surface methodology is a statistical method used to improve and optimize process. The response surface methodology has the advantages to evaluate multiple processing parameters and reduced the number of experimental trials. The experimental results were evaluated by the dependent variables of thermoelectric efficiency using Design Expert 8 [12] with surface response model. The results are obtained with the experimental design that was aimed at identifying the best levels of the $\mathrm{Al}$ doping $(0-4 \mathrm{wt} . \%)$ and sintering temperature $\left(800-1000{ }^{\circ} \mathrm{C}\right)$. The analysis of variance (ANOVA) is a statistical technique for the purpose of testing hypotheses on the parameters of the model. A 3-factor, 3-level factorial Box-Behnken design (BBD) was employed to investigate the effects of selected variables. BBD which is a widely used form of response surface methodology, specially made to require only 3 levels, coded as $-1,0$, and +1 . BBD is an independent, rotatable or nearly rotatable quadratic design (contains no embedded factorial or fractional factorial design) in which the treatment combinations are at the midpoints of the edges of the process space and at the centre.

\section{Computational method}

The ABINIT program was used to perform the band structure calculations. ABINIT is an open source program that used to compute band structure and ground state properties. The band structures of $\mathrm{Al}$ doped $\mathrm{ZnO}$ was calculated based on the DFT Kohn-Sham equations with GW computations. The GW method is a Green function technique that obtained the electron self-energy and provides an accurate determination of the quasiparticle excitation energies [13]. The k-point parameter was 3 × $3 \times 1$ Monkhorst-Pack. The cut off energy was set to be $816 \mathrm{eV}$ (30 hartree). The ideal $\mathrm{ZnO}$ has a wurtzite structure at normal temperatures and pressures. The primitive cell parameters for ideal $\mathrm{ZnO}$ were determined as $\alpha=3.2005 \AA, \mathrm{c} / \alpha=1.6131$ and $\mathrm{u}=0.3792$. The parameters used in ABINIT were optimized with a convergence criterion $0.01 \mathrm{eV}$ to calculate self-energy for the band gap.

\section{XRD analysis}

\section{Results and Discussion}

Based on Figure 1(a), all the samples peaks for $0,1,2,3$ and 4 wt.\% Al-doped $\mathrm{ZnO}$ were identified as the plane reflection for wurtzite phase of $\mathrm{ZnO}$ according to the JCPDS data file (No. 36-1451). The XRD pattern of Al-doped $\mathrm{ZnO}$ sintered at $900{ }^{\circ} \mathrm{C}$ was indicated in Figure 1(b). Based on the test results, all the peaks for $0,1,2,3$ and 4 wt. $\%$ Al-doped $\mathrm{ZnO}$ matched the JCPDS data file (No.36-1451) as the plane reflection for wurtzite phase of ZnO. There was additional phase $\mathrm{ZnAl}_{2} \mathrm{O}_{4}$ that matched the JCPDS data file (No.05-0669) detected for 4 wt.\% Al-doped $\mathrm{ZnO}$ sintered at $900{ }^{\circ} \mathrm{C}$. From the test results show in Figure 1(c), additional phase $\mathrm{ZnAl}_{2} \mathrm{O}_{4}$ was detected for 3 wt. $\%$ and 4 wt.\% Al-doped $\mathrm{ZnO}$ with the sintering temperature increased to $1000{ }^{\circ} \mathrm{C}$. The existence of secondary phase $\mathrm{ZnAl}_{2} \mathrm{O}_{4}$ may reduce the electrical conductivity of the sample [14].

\section{Electrical conductivity}

Based on the analysis of variance (ANOVA) for electrical conductivity as shown in Table 2, the Model F-value of 404.80 implies the model was significant. The Prob > F values of less than 0.05 may indicate that Al dopants and sintering temperature have significant effects on the electrical conductivity of the samples. 


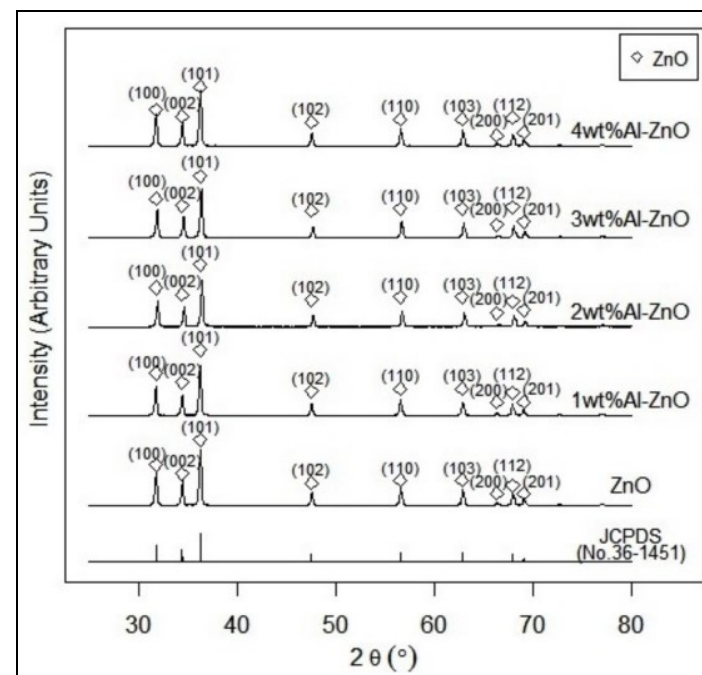

(a) $800^{\circ} \mathrm{C}$

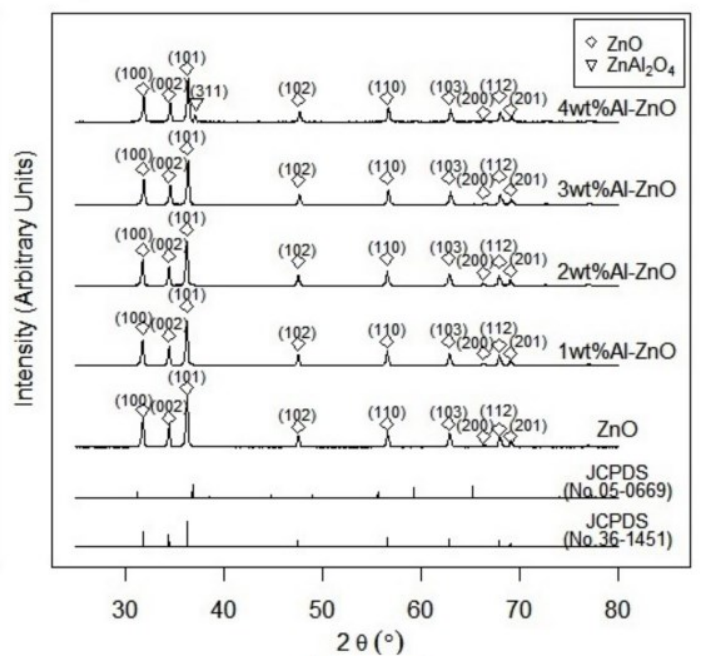

(b) $900^{\circ} \mathrm{C}$

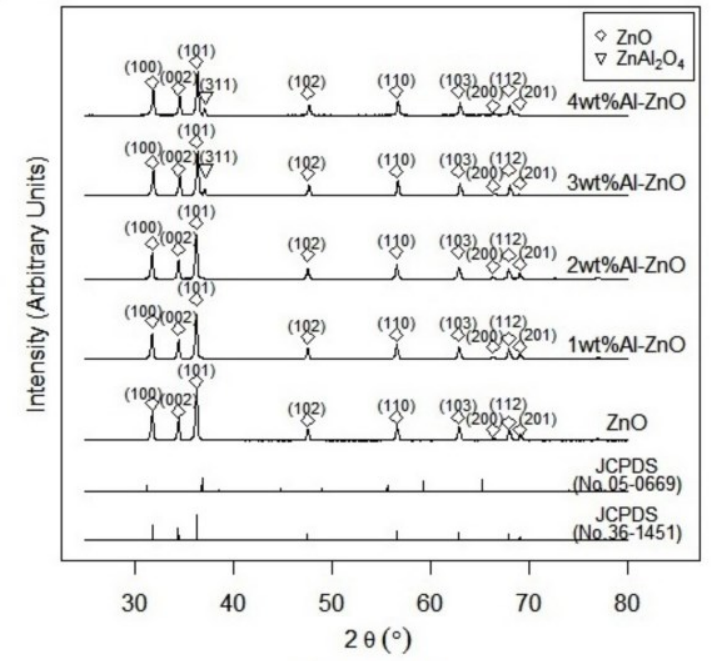

(c) $1000^{\circ} \mathrm{C}$

Figure 1. XRD pattern of Al-doped $\mathrm{ZnO}$ sintered at (a) $800{ }^{\circ} \mathrm{C}$ (b) $900{ }^{\circ} \mathrm{C}$ (c) $1000{ }^{\circ} \mathrm{C}$

Table 2. Analysis of variance for electrical conductivity

\begin{tabular}{llllll}
\hline Source & $\begin{array}{l}\text { Sum of } \\
\text { Squares }\end{array}$ & Df & $\begin{array}{l}\text { Mean } \\
\text { Square }\end{array}$ & F value & $\begin{array}{l}\text { p-value } \\
\text { Prob }>\text { F }\end{array}$ \\
\hline Model & 8219.08 & 5 & 1643.82 & 404.80 & $<0.0001$ \\
A-Al dopants & 7360.83 & 1 & 7360.83 & 1812.63 & $<0.0001$ \\
B-Sintering temperature & 14.18 & 1 & 14.18 & 3.49 & 0.0245 \\
AB & 12.31 & 1 & 12.31 & 3.03 & 0.1157 \\
$\mathrm{~A}^{2}$ & 831.35 & 1 & 831.35 & 204.72 & $<0.0001$ \\
$\mathrm{~B}^{2}$ & 0.41 & 1 & 0.41 & 0.100 & 0.7591 \\
Residual & 36.55 & 9 & 4.06 & & \\
Cor Total & 8255.62 & 14 & & & \\
\hline
\end{tabular}


Figure 2 show the 3D plot for electrical conductivity profile in accordance to the response surface model. The highest peak electrical conductivity for $\mathrm{ZnO}$ was achieved with $4 \mathrm{wt} . \% \mathrm{Al}$ dopants sintered at temperature $800{ }^{\circ} \mathrm{C}$. Based on results shown in Figure 2, increasing the concentration of Al dopant caused a significant increase in the electrical conductivity. This might due to the $\mathrm{Al}$ dissolved in the $\mathrm{ZnO}$ crystal lattice acts as donor [15]. For example, the electrical conductivity of bulk pellets was increased significantly from $9.95 \mathrm{~S} / \mathrm{cm}$ (pure $\mathrm{ZnO}$ ) to $37.39 \mathrm{~S} / \mathrm{cm}$, $59.38 \mathrm{~S} / \mathrm{cm}, 69.26 \mathrm{~S} / \mathrm{cm}$ and $71.49 \mathrm{~S} / \mathrm{cm}$ as the dopant increased to $1,2,3$ and $4 \mathrm{wt} . \%$ respectively. The electrical conductivity for 4 wt. $\%$ Al-doped $\mathrm{ZnO}$ sintered in air at $1000{ }^{\circ} \mathrm{C}(70.98 \mathrm{~S} / \mathrm{cm})$ and $900{ }^{\circ} \mathrm{C}(71.49 \mathrm{~S} / \mathrm{cm})$ were slightly lower compared to $800{ }^{\circ} \mathrm{C}(71.87 \mathrm{~S} / \mathrm{cm})$. This might due to the existence of $\mathrm{ZnAl}_{2} \mathrm{O}_{4}$ phase as shown in Figure 1. The $\mathrm{ZnAl}_{2} \mathrm{O}_{4}$ phase believed to induce oxygen vacancies that lead to low conductivity. The formation of this phase may cause the resistivity increase in the samples [16].

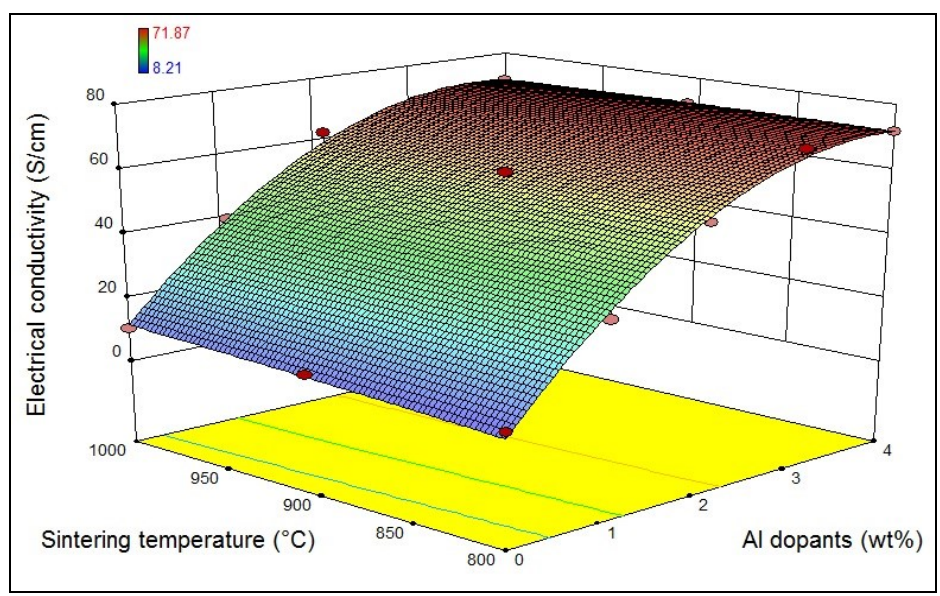

Figure 2. 3D response surface plot for electrical conductivity of Al-doped $\mathrm{ZnO}$

\section{Band structure}

The electronic band structure for $\mathrm{ZnO}$ calculated using DFT was shown in Figure 3. The band structure shows that $\mathrm{ZnO}$ is direct band gap material with the valence band maximum (VBM) and the conduction band minimum (CBM) at $\mathrm{G}$. The calculated band gap at point $\mathrm{G}$ is $0.749 \mathrm{eV}$ for $\mathrm{ZnO}$. Low band gap might be due to the lower exchange correlation between electrons made by the DFT-GW function.

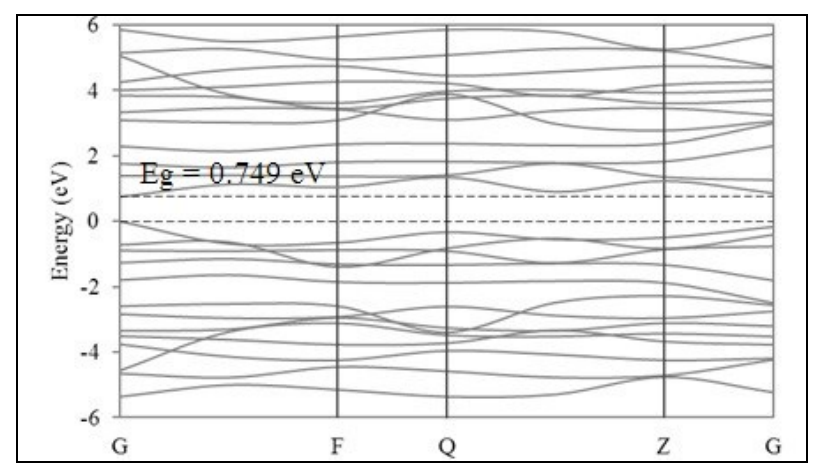

Figure 3. Electronic band structure of pure $\mathrm{ZnO}$ 


\section{Lim et al: OPTIMIZATION PARAMETER FOR THERMOELECTRIC PROPERTIES OF ZnO USING}

RESPONSE SURFACE METHODOLOGY

Figure 4(a)-(d) shows the calculated band structure of 1 wt.\% Al-ZnO, 2 wt.\% Al-ZnO, 3 wt.\% Al-ZnO and 4 wt.\% Al-ZnO respectively, the corresponding band gap are $0.684 \mathrm{eV}, 0.619 \mathrm{eV}, 0.557 \mathrm{eV}$ and $0.551 \mathrm{eV}$. The band gap values of $\mathrm{Al}$ doped $\mathrm{ZnO}$ are smaller than pure $\mathrm{ZnO}$ shown in Figure 3. The band gap of $\mathrm{Al}$ doped $\mathrm{ZnO}$ becomes smaller with increasing $\mathrm{Al}$ doping content. This may due to increase of carrier concentration and enhancement of conduction [19]. As shown from Figure 4(a)-(d), The CBM and VBM are all located in the G point, it indicated that $\mathrm{Al}$ doped $\mathrm{ZnO}$ is a direct band gap semiconductor. The electrical conductivity test results were similar to the calculated band gap. The band gap becomes smaller with the amounts of Al doping increased that resulting an increase in electrical conductivity. This emphasized that a reduction of the band gap would increase the intrinsic (without defects) conductivity of $\mathrm{ZnO}$. It shifts the intrinsic defect states to energies inside the conduction band.

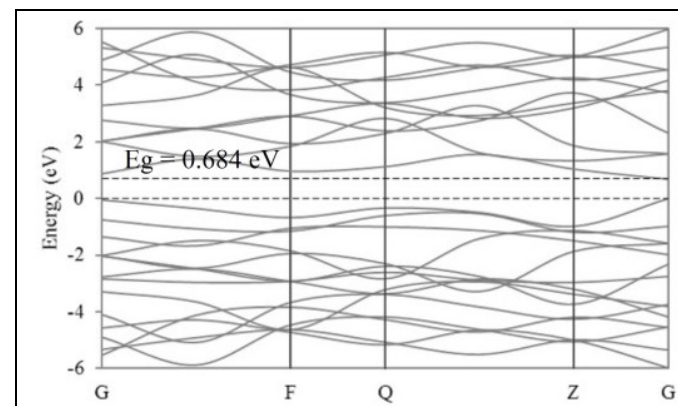

(a) $1 \mathrm{wt} \% \mathrm{Al}-\mathrm{ZnO}$

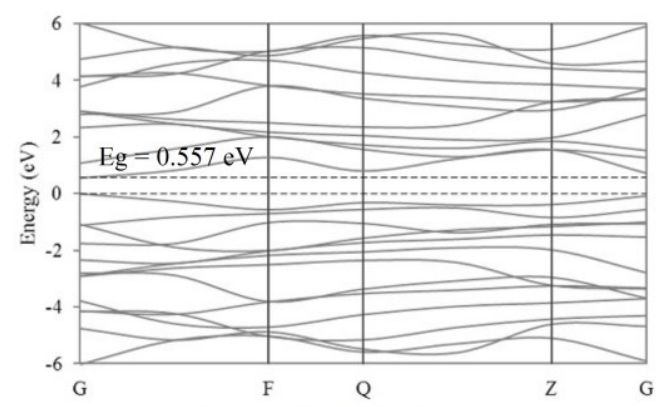

(c) $3 \mathrm{wt} \% \mathrm{Al}-\mathrm{ZnO}$

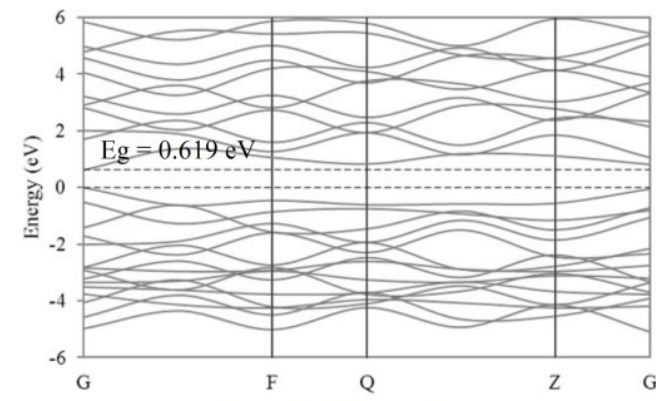

(b) $2 \mathrm{wt} \% \mathrm{Al}-\mathrm{ZnO}$

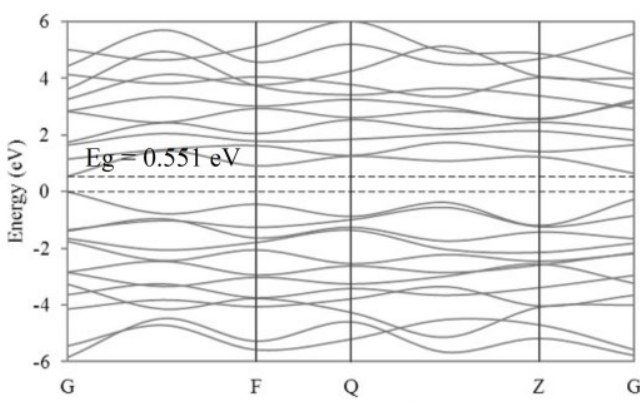

(d) $4 \mathrm{wt} \% \mathrm{Al}-\mathrm{ZnO}$

Figure 4. Electronic band structure of $\mathrm{Al}$ doped $\mathrm{ZnO}$

\section{Thermal conductivity}

Table 3 show the analysis of variance (ANOVA) output used to estimate the variation due to each factor. The Model F-value of 51477.35 implies the model was significant. Values of "Prob > F" less than 0.05 indicate the model terms are significant. The ANOVA indicates that changing the sintering temperature and Al dopants may have a significant effect on the thermal conductivity of the samples.

The highest peak thermal conductivity for $\mathrm{ZnO}$ was achieved for pure $\mathrm{ZnO}$ sintered at $800^{\circ} \mathrm{C}$. Based on results shown in Figure 5, increasing the amount of Al dopants caused a decrease in the thermal conductivity of the samples. The thermal conductivity of $\mathrm{ZnO}$ was $34.59 \mathrm{~W} / \mathrm{mK}$ reduced to $33.21 \mathrm{~W} / \mathrm{mK}, 31.82 \mathrm{~W} / \mathrm{mK}, 30.44 \mathrm{~W} / \mathrm{mK}$ and $29.05 \mathrm{~W} / \mathrm{mK}$ with the Al doping increased to $1,2,3$ and $4 \mathrm{wt} \%$ respectively. The reduction of thermal conductivity might due to the Al dopant suppress the lattice thermal conductivity of $\mathrm{ZnO}$ materials [20]. The thermal conductivity of the $\mathrm{ZnO}$ pellets decreased slightly when increasing the amount of $\mathrm{Al}$ dopants. The wurtzite $\mathrm{ZnO}$ has a high intrinsic thermal conductivity due to its strong covalent bonding and light atoms. The decrease in the thermal conductivity might be due to a phonon scattering caused by increased $\mathrm{ZnO}$ crystal lattice disorder when 
$\mathrm{Al}$ dopants were added.

Table 3. Analysis of variance for thermal conductivity

\begin{tabular}{llllll}
\hline Source & $\begin{array}{l}\text { Sum of } \\
\text { Squares }\end{array}$ & Df & $\begin{array}{l}\text { Mean } \\
\text { Square }\end{array}$ & F value & $\begin{array}{l}\text { p-value } \\
\text { Prob }>\text { F }\end{array}$ \\
\hline Model & 83.85 & 5 & 16.77 & 51477.35 & $<0.0001$ \\
A-Al dopants & 56.42 & 1 & 56.42 & $1.732 \mathrm{E}+005$ & $<0.0001$ \\
B-Sintering temperature & 26.67 & 1 & 26.67 & 81852.09 & $<0.0001$ \\
$\mathrm{AB}$ & 0.099 & 1 & 0.099 & 305.12 & $<0.0001$ \\
$\mathrm{~A}^{2}$ & $9.524 \mathrm{E}-006$ & 1 & $9.524 \mathrm{E}-006$ & 0.029 & 0.8680 \\
$\mathrm{~B}^{2}$ & 0.67 & 1 & 0.67 & 2062.67 & $<0.0001$ \\
Residual & $2.932 \mathrm{E}-003$ & 9 & $3.258 \mathrm{E}-004$ & & \\
Cor Total & 83.86 & 14 & & & \\
\hline
\end{tabular}

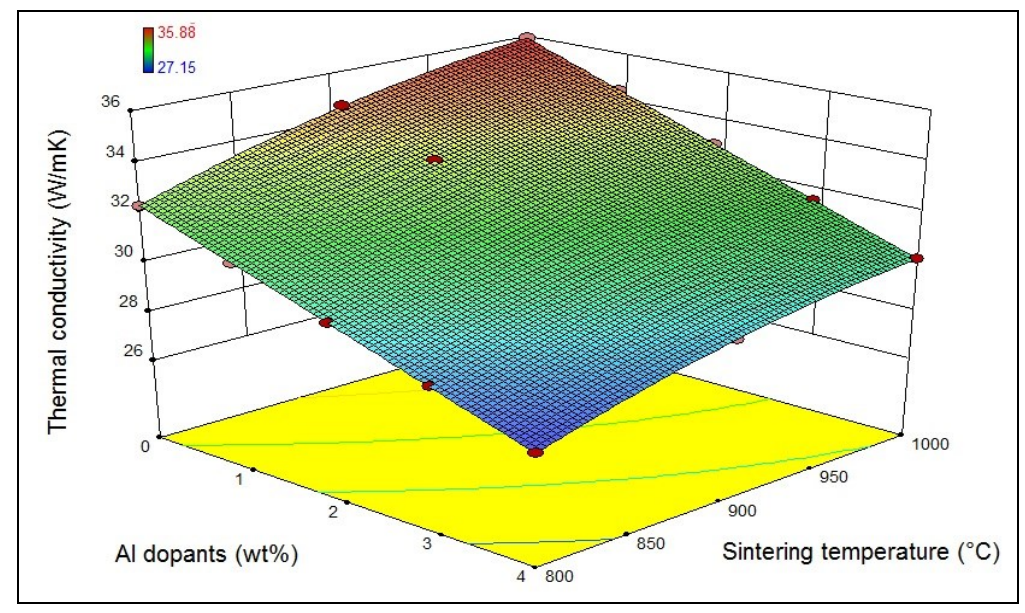

Figure 5. 3D response surface plot for thermal conductivity of Al-doped $\mathrm{ZnO}$

\section{Seebeck coefficient}

Based on the analysis of variance for Seebeck coefficient as shown in Table 4, the Model F-value of 370.54 implies the model was significant. The Prob $>$ F values below 0.05 may indicate that the sintering temperature and $\mathrm{Al}$ dopants have a significant effect on the Seebeck coefficient.

Figure 6 show a 3D plot curvilinear profile in accordance to the response surface model for the Seebeck coefficient. The highest peak Seebeck coefficient for $\mathrm{ZnO}$ was achieved for pure $\mathrm{ZnO}$ sintered at $1000{ }^{\circ} \mathrm{C}$. Based on results shown in Figure 6, an increase in the Al doping concentration caused a decrease in the Seebeck coefficient of the bulk pellets. This might due to the $\mathrm{Al}$ dissolved in the $\mathrm{ZnO}$ crystal lattice acts as donor that improved the electrical conductivity and carrier concentration [21]. The negative sign of the Seebeck values was used to indicate the samples were n-type semiconductors. The magnitude of Seebeck coefficient for $\mathrm{ZnO}$ was $50.22 \mu \mathrm{V} / \mathrm{K}$ decreased to $49.22 \mu \mathrm{V} / \mathrm{K}, 48.71 \mu \mathrm{V} / \mathrm{K}, 48.21 \mu \mathrm{V} / \mathrm{K}$ and $47.95 \mu \mathrm{V} / \mathrm{K}$ with the $\mathrm{Al}$ dopant increased to $1,2,3$ and 4 wt.\% respectively. 


\section{Lim et al: OPTIMIZATION PARAMETER FOR THERMOELECTRIC PROPERTIES OF ZnO USING}

RESPONSE SURFACE METHODOLOGY

Table 4. Analysis of variances for Seebeck coefficient

\begin{tabular}{llllll}
\hline Source & $\begin{array}{l}\text { Sum of } \\
\text { Squares }\end{array}$ & Df & $\begin{array}{l}\text { Mean } \\
\text { Square }\end{array}$ & F value & $\begin{array}{l}\text { p-value } \\
\text { Prob }>\text { F }\end{array}$ \\
\hline Model & 16.48 & 5 & 3.30 & 370.54 & $<0.0001$ \\
A-Al dopants & 10.33 & 1 & 10.33 & 1160.46 & $<0.0001$ \\
B-Sintering temperature & 5.63 & 1 & 5.63 & 632.19 & $<0.0001$ \\
AB & $4.805 \mathrm{E}-003$ & 1 & $4.805 \mathrm{E}-003$ & 0.54 & 0.4811 \\
$\mathrm{~A}^{\wedge} 2$ & 0.40 & 1 & 0.40 & 44.54 & $<0.0001$ \\
$\mathrm{~B}^{\wedge} 2$ & 0.13 & 1 & 0.13 & 14.99 & 0.0038 \\
Residual & 0.080 & 9 & $8.898 \mathrm{E}-003$ & & \\
Cor Total & 16.56 & 14 & & & \\
\hline
\end{tabular}

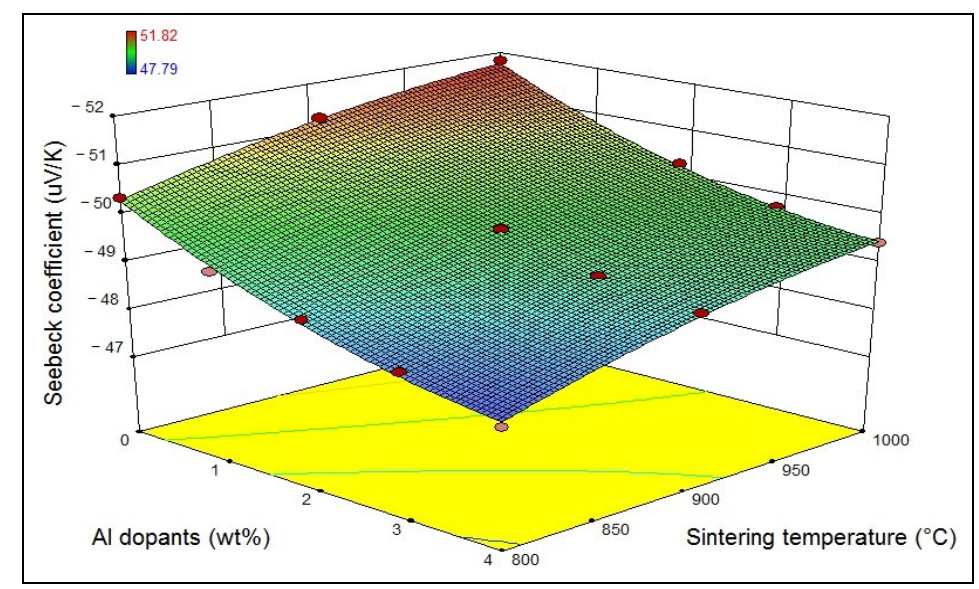

Figure 6. 3D response surface plot for Seebeck coefficient of Al-doped $\mathrm{ZnO}$

\section{Thermoelectric figure of merit}

The thermoelectric figure of merit calculated from the measured values of electrical conductivity, Seebeck coefficient and thermal conductivity was shown in Figure 7. Higher figure of merit values $(0.61)$ was observed for 4 wt. $\%$ Al-doped $\mathrm{ZnO}$ pellet sintered at $800^{\circ} \mathrm{C}$. The figure of merit for Al-doped $\mathrm{ZnO}$ was improved by doping $\mathrm{Al}$. The figure of merit for $4 \mathrm{wt} . \% \mathrm{Al}$-doped $\mathrm{ZnO}$ sintered at $800{ }^{\circ} \mathrm{C}$ was higher $\left(\mathrm{Z} \sim 0.58 \times 10^{-6}\right)$ due to high electrical conductivity and low thermal conductivity was obtained when increasing $\mathrm{Al}$. The figure of merit for Al-doped $\mathrm{ZnO}$ $\left(\mathrm{Al}>3\right.$ wt.\%) was decreased when increasing sintering temperature. This was due to the formation of $\mathrm{ZnAl}_{2} \mathrm{O}_{4}$ phase at higher sintering temperature that lead to the reduction of electrical conductivity [22]. The presence of $\mathrm{ZnAl}_{2} \mathrm{O}_{4}$ phase was observed to reduce the figure of merit compared to single $\mathrm{ZnO}$ phase samples. This indicated the additional $\mathrm{ZnAl}_{2} \mathrm{O}_{4}$ phases had a deleterious effect on the thermoelectric properties. 


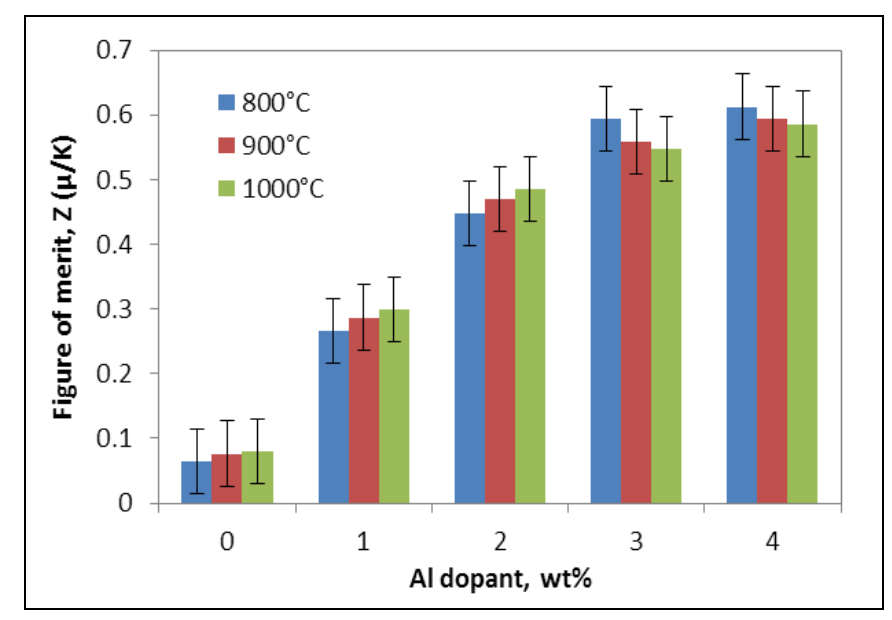

Figure 7. Figure of merit of Al-doped $\mathrm{ZnO}$

\section{Conclusion}

Thermoelectric properties of $\mathrm{ZnO}$ were improved with increasing the amount of $\mathrm{Al}$ dopants. The thermoelectric figure of merit for $4 \mathrm{wt} . \% \mathrm{Al}$-doped $\mathrm{ZnO}(0.61)$ yielding a 10 times enhancement compared to the pure $\mathrm{ZnO}(0.06)$. The electrical conductivity of Al-doped $\mathrm{ZnO}$ was increased with increasing the amount of Al dopants. The Seebeck coefficient and thermal conductivity were decreased for Al-doped $\mathrm{ZnO}$ with increasing the amount of Al dopants. Thermoelectric properties of $\mathrm{Al}$-doped $\mathrm{ZnO}$ were decreased with increasing the sintering temperature due to the additional phase $\mathrm{ZnAl}_{2} \mathrm{O}_{4}$. The thermoelectric figure of merit for 4 wt.\% Al-doped $\mathrm{ZnO}(0.61)$ with lower sintering temperature $\left(800^{\circ} \mathrm{C}\right)$ was higher compared to the 4 wt. $\%$ Al-doped $\mathrm{ZnO}(0.58)$ sintered at higher temperature $(1000$ $\left.{ }^{\circ} \mathrm{C}\right)$. Based on the analysis of variance, the sintering temperature and $\mathrm{Al}$ dopants have a significant effect to the thermoelectric properties of $\mathrm{Al}$ doped $\mathrm{ZnO}$. Based on the response surface, the optimum values for this study were $\mathrm{Al}$ dopant $(4 \mathrm{wt} . \%)$ and sintering temperature $\left(800^{\circ} \mathrm{C}\right)$. By using the first principles method based on DFT, the band structure of $\mathrm{ZnO}$ and $\mathrm{Al}$ doped $\mathrm{ZnO}$ were calculated. The band structure calculation of $\mathrm{Al}$ doped $\mathrm{ZnO}$ was investigated to provide a reference values for the electrical conductivity. Based on the DFT calculation, $\mathrm{ZnO}$ is a direct band gap. The band gap getting narrow as the concentration of Al doping increased from $1 \mathrm{wt} . \%(0.684 \mathrm{eV})$ to 4 wt.\% $(0.551 \mathrm{eV})$ compare to pure $\mathrm{ZnO}(0.749 \mathrm{eV})$.

\section{Acknowledgement}

The financial support of Fundamental Research Grant Scheme (FRGS) grant no 9003-00392 is gratefully acknowledged.

\section{References}

1. Tritt, T. M. (2011). Thermoelectric phenomena, materials, and applications. Annual Review of Materials Research, 41(1):433 - 448.

2. Cheng, H., Xu, X. J., Hng, H. H. and Ma, J. (2009). Characterization of Al-doped ZnO thermoelectric materials prepared by RF plasma powder processing and hot press sintering. Ceramics International, 35(8):3067 - 3072.

3. Goldsmid, H. (2010). Application of the transverse thermoelectric effects. Journal of Electronic Materials, 1:1 -6 .

4. Huang, M. H., Mao, S., Feick, H., Yan, H., Wu, Y., Kind, H., Weber, E., Russo, R. and Yang. P. (2001). Room-temperature ultraviolet nanowire nanolasers. Science, 292:1897-1899.

5. Ried, R. P., Kim, E., Hong, D. M. and Muller, R. S. (1993). Piezoelectric microphone with on-chip CMOS circuit. Journal of Microelectromechanical Systems, 2: 111 - 120.

6. Ito, Y., Kushida, K., Sugawara, K. and Takeuchi, H. (1995). A 100-Mhz ultrasonic transducer array using ZnO thin films. IEEE Transaction on Ultrasonic, Ferroelectric and Frequency Control, 42: 316 - 323. 
7. Burdett, J. K., Price, G. D. and Price, S. L. (1982). Role of the crystal field theory in determining the structures of spinels. Journal of the American Chemical Society, 104(1): 92 - 95.

8. Yan, X. D., Han, J., Chen, R. Q., Gao, W., Metson, J. and Zou., C. W. (2009). Study of a nitrogen-doped ZnO film with synchrotron radiation. Applied Physics Letters, 94: 171903.

9. Jimenez-Gonzalez, A. E., Jose A., Urueta, S. and Suarez-Parra, R. (1998). Optical and electrical characteristics of aluminum-doped $\mathrm{ZnO}$ thin films prepared by sol-gel technique. Journal of Crystal Growth, 192: 430 - 438 .

10. Look, D. C. (2001). Recent advances in ZnO materials and devices. Materials Science and Engineering B, 80(1-3): $383-387$.

11. Ravinder, D. (1999). Thermoelectric power studies of zinc substituted copper ferrites. Journal of Alloys and Compounds, 291(1-2): $208-214$.

12. Inc.Stat-Ease. (2007). Design Expert Software, Educational Version 7.0.3, Wiley Publishing.

13. Gonze, X., Amadon, B., Anglade, P. M., Beuken, J. M., Bottin, F. and Boulanger, P. (2009). ABINIT: firstprinciples approach to material and nanosystem properties. Computer Physical Communication, 180: $2582-$ 2615.

14. Takagi, Y., Ito, M., Majima, K., Nagai, H., and Katsuyama, S. (2002). Thermoelectric properties of $\left(\mathrm{Zn}_{\mathrm{y}} \mathrm{Mg}_{\mathrm{y}}\right) 1_{\mathrm{x}} \mathrm{Al}_{\mathrm{x}} \mathrm{O}$ ceramics prepared by the polymerized complex method. Journal of Applied Physics, 92: $1391-1398$.

15. Qu, X., Wang, W., Lv, S., and Jia, D. (2011). Thermoelectric properties and electronic structure of Al-doped ZnO. Solid State Communications, 151(4): 332 - 336.

16. Han, J., Mantas, P. Q., and Senos, A.M.R. (2001). Effect of Al and Mn doping on the electrical conductivity of ZnO. Journal of the European Ceramic Society, 21(10-11): 1883 - 1886.

17. Zhang, M., Zhang, C. H. and Shen, J. (2011). First-principles calculation of electronic structure of $\mathrm{Mg}_{\mathrm{x}} \mathrm{Zn} 1-_{\mathrm{x}} \mathrm{O}$ codoped with aluminium and nitrogen. Chinese Physics B, 20: 017101.

18. Yang, P., Zhao, Y. and Yang, H. (2015). Investigation on optoelectronic performances of Al, N codoped ZnO: First-principles method. Ceramics International, 41: $2446-2452$.

19. Li, P., Deng, S. H., Li, Y. B., Huang, J., Liu, G. H. and Zhang, L. (2011). Aluminum and nitrogen impurities in Wurtzite ZnO: first-principles studies, Physica B, 406: 3125 - 3129.

20. Ozgur, U., Ya, Liu, C., Teke, A., Reshchikov, M. A., Dogan, S., V., Avrutin, Cho, S. J. and Morkoc, H. (2005). A comprehensive review of $\mathrm{ZnO}$ materials and devices. Journal of Applied Physics, 98(4): 1 -103.

21. Bhan, R. and Dhar, V. (2004). Carrier density approximation for non-parabolic and highly degenerated HgCdTe semiconductors. Semiconductor Science and Technology, 19(3): 413 - 416.

22. Cheng, H., Xu, X. J., Hng, H. H. and Ma, J. (2009). Characterization of Al-doped ZnO thermoelectric materials prepared by RF plasma powder processing and hot press sintering. Ceramics International, 35(8): 3067 - 3072. 